\title{
Neo-Eskimo Occupations of the Northern Labrador Coast
}

\author{
SUSAN A. KAPLAN
}

\begin{abstract}
Archaeological and historical information are brought together in an examination of the changing economic and social interaction spheres of the Labrador Neo-Eskimo from the Thule period through the 19th century. Animal availability, hunting technologies and strategies, and direct and indirect contact between Neo-Eskimos and various European groups are considered in a discussion of changing subsistence practices and settlement patterns. The paper pin-points a pattern of intensification and eventual disintegration of cooperative endeavours between Neo-Eskimo groups inhabiting northern Labrador.
\end{abstract}

RÉSUMÉ. C'est à partir d'informations archéologiques et historiques réunies ensemble que s'est fait l'examen des changements économiques et sociaux intéressant les Esquimaux du Labrador depuis la période de Thule jusqu'au 19ème siècle. Les animaux disponibles, les technologies et stratégies intéressant la chasse, les contacts directs et indirects entre ces Esquimaux et des groupes Européens variés, sont les facteurs à considérer dans l'étude des changements dans le mode de subsistance et de colonisation. L'article insiste sur les efforts de coopération entre les groupes "Neo-Esquimaux" habitant le Labrador septentrional. C'est un exemple d'intensification et d'une éventuelle désintégration de ces efforts.

Traduit par Alain de Vendegies, Aquitaine Company of Canada Ltd.

\section{INTRODUCTION}

During the summers of 1977 and 1978 members of the Torngat Archaeological Project conducted surveys along the northern Labrador coast, between the Kaumajet Mountains and the Button Islands, in order to determine the distribution, nature, and extent of human occupations along this coastal region. The present paper is of a preliminary nature, and presents some of the results of investigations concerning Neo-Eskimo occupations of northern Labrador. The paper brings together archaeological and historical information and discusses factors which brought about changes in the economic and social interaction spheres of the Eskimo population inhabiting northern Labrador from the Thule period through the 19th century.

Initially, major fiord and island systems between the Kaumajet Mountains and the Button Islands (Fig. 1) were surveyed by four two-man teams. Two research vessels, the R/V Pitsiulak and the R/V Tunuyak carried the survey teams, as well as a geologist and a botanist, north from Nain, presently the northernmost inhabited settlement on the Labrador coast. Outboard motor boats and canoes facilitated movement within survey areas, while the actual surveys were conducted on foot.

During the second field season float planes flew three small land-based archaeological teams into Seven Islands Bay. Two of these teams were then transported into the Home Island region by the R/V Pitsiulak. The land-based crews further tested and in some cases excavated important Paleo-Eskimo and Neo-Eskimo structures. Meanwhile, two other archaeology teams and a party of geologists continued boat-supported surveys. 


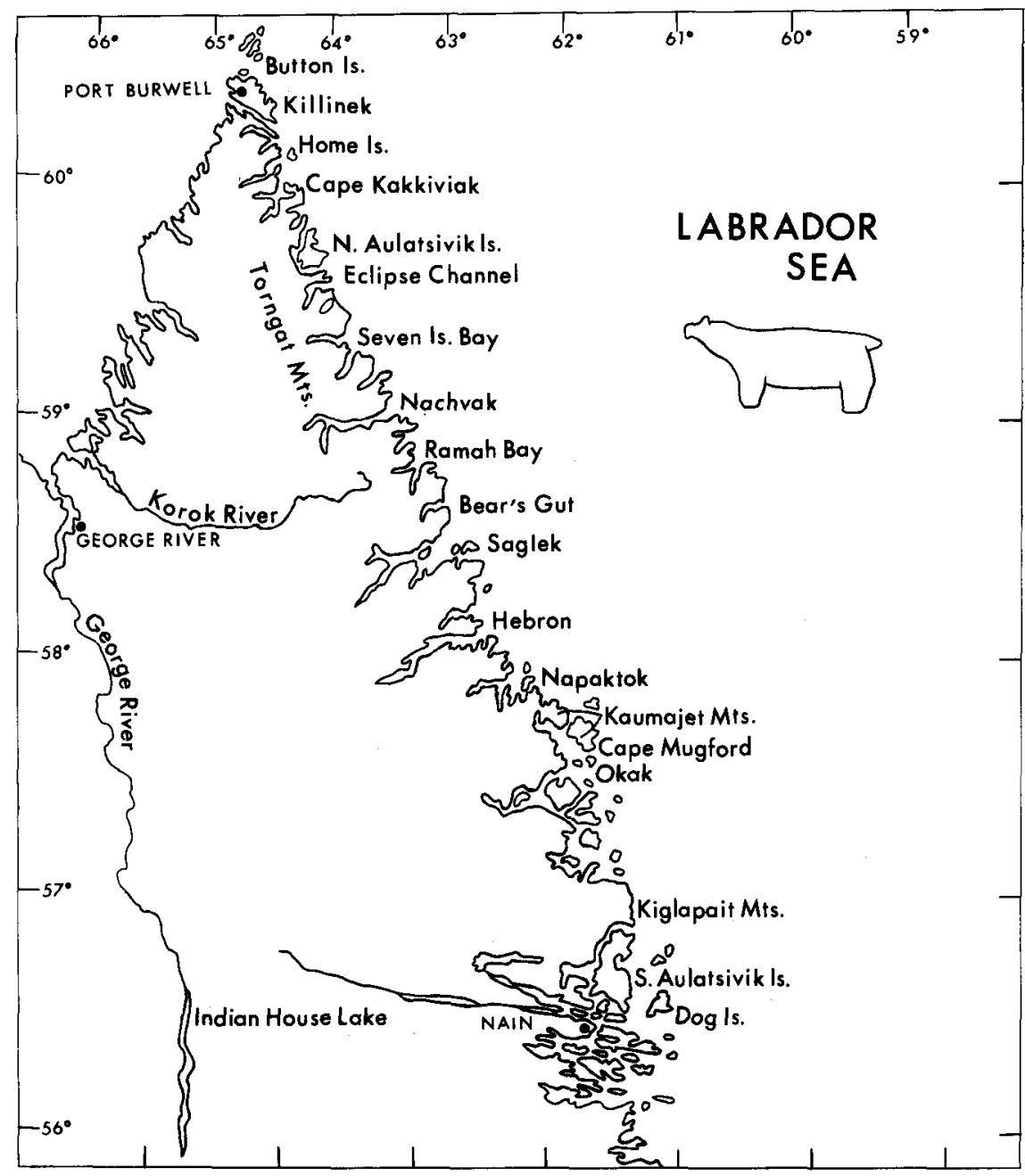

FIG. 1. Geography of northern Labrador.

The Neo-Eskimo cultural chronology is being established through various dating techniques. Charcoal samples, taken from apparent Thule deposits, have been submitted to the Smithsonian Radiation Biology Laboratory, in attempts to determine the length of the Thule occupation of the northern Labrador coast and the relationship between Late Dorset and Thule occupations. Traditional Eskimo artifacts are being compared with those from other sites in the Arctic for dating purposes. Materials of European manufacture are also being analyzed. In this regard, the temporal sensitivity of the artifact is considered, as are problems relating to trade and curation.

Throughout this study a distinction between pre-contact and contact sites is made for culture historical and analytical reasons. While Schledermann (1971) has discussed the transition from the Thule to the historic period in his Saglek 
work, the economic and social implications of this transition have not been investigated. It is clear that contact occurred at different times along the Labrador coast, and the nature of the contact also varied. Schledermann (1971:20) was quite aware of this when he noted "The presence of contact material does not necessarily mean face to face contact. While Eskimos are historic in some areas of Labrador they are prehistoric in others.' These two points must be kept in mind when discussing Eskimo-European contact situations on the northern Labrador coast.

\section{DISCUSSION \\ Early Neo-Eskimo Patterns}

\section{Thule Period}

Thule people moved into northern Labrador $c$. 1400 A.D. (Schledermann, 1971:69). Whether they came by way of Ungava Bay, or from Baffin Island, is unclear. Structures and artifacts from McLelan Strait, the Home Islands, Seven Islands Bay, Nachvak Fiord, Saglek Bay and Hebron Fiord (Fig. 2) indicate that they inhabited major island and fiord systems between the tip of Labrador and the Kaumajet Mountains.

The southernmost extension of Thule peoples is unknown, due to lack of work relating to this time period in the Okak and Nain areas. Whether the Thule people displaced or intermingled with the Labrador Late Dorset population is unclear, as is the question of Thule contact with Point Revenge Indian groups.

Thule sod house settlements are located near year-round open water zones or in areas close to the sina, indicating a strong maritime subsistence orientation. Whale and walrus remains associated with the Thule settlements suggest a major focus on the procurement of large sea mammals. A variety of other animals are represented in midden deposits, indicating that ring, harp and bearded seals, as well as caribou, were hunted.

The diversity of animals represented at a Thule site reflects the great mobility of the hunters, who covered a wide range of hunting zones using boats and dog sleds while maintaining settlements in one area. Hunting was probably a cooperative venture; caribou drives, whale and walrus hunting and butchering would have involved large numbers of people.

At present, the nature and extent of contact between Thule groups inhabiting various fiords and islands of the Labrador coast are not known. Slate, nephrite, soapstone, wood, ivory, feathers, and caribou skins are among the items which may have moved through early networks. Interaction, in the form of cooperative hunts, social events, and trade relationships probably established and strengthened formal and informal ties between individuals in various communities.

\section{Seventeenth Century}

European-Eskimo contact sites dating to the 17th century have not been located on the northern coast. In all likelihood Eskimos were visited periodically by Dutch whalers during this time (Kupp and Hart, 1976). However, judging from the 1550 A.D. date from a Thule level at Nunaingoak 1 (JcDe-1), in 


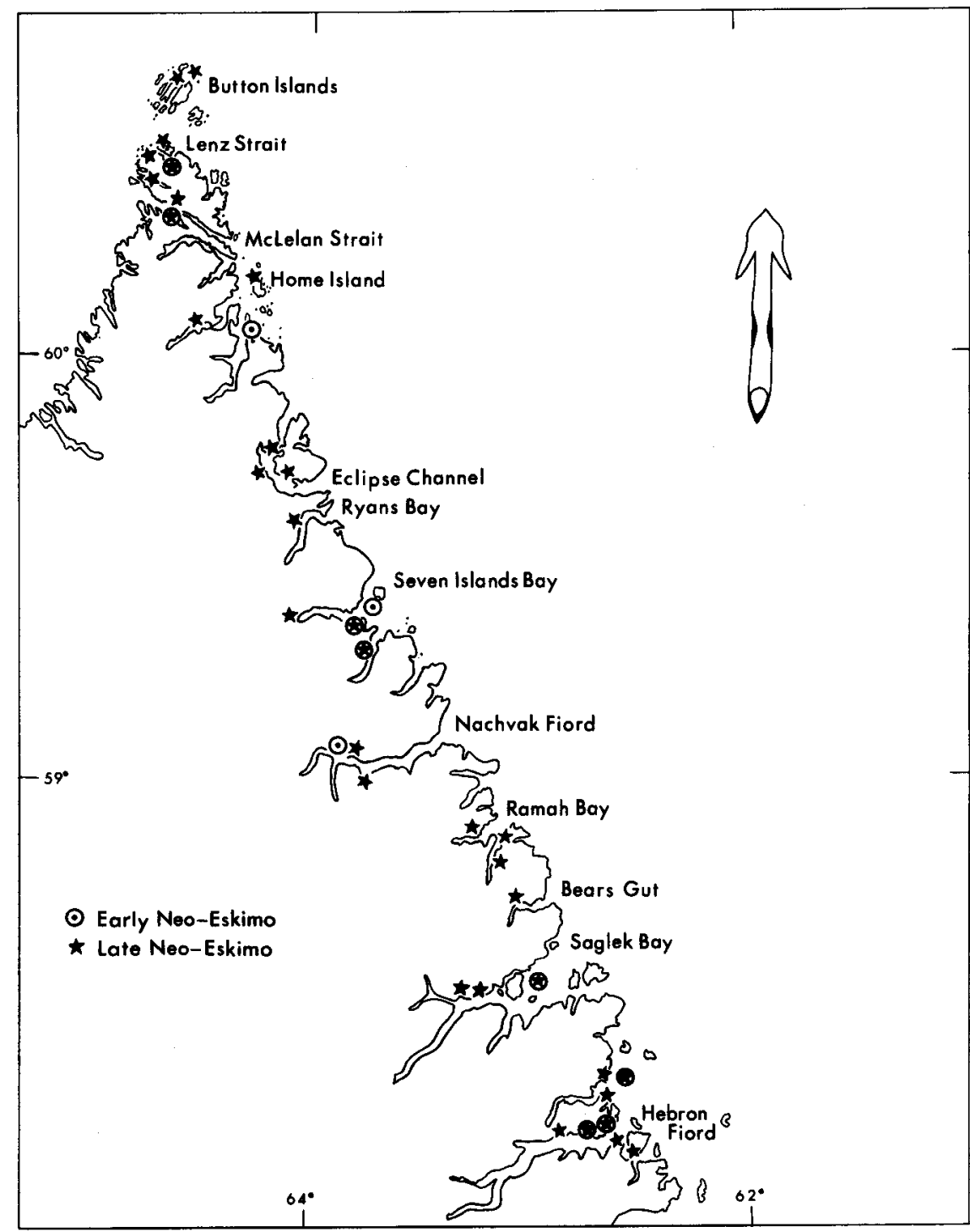

FIG. 2. Neo-Eskimo sod house village locations.

McLelan Strait, it seems reasonable to suggest that the Thule tradition continued throughout most of the 17 th century. Local resource specializations may have developed; population growth and dispersal took place.

Examinations of archaeological collections from Eskimo Island (Jordan, 1974;1978) and Hopedale (Bird, 1945), in southern Labrador, reveal that the Neo-Eskimo population had expanded south to Hamilton Inlet by the late 1600 's, and that a wealth of French articles were in the hands of these southern Eskimo communities. The French were in the area seeking seal skins, baleen, and blubber. There was some trade of European goods to the Eskimos in 
exchange for these items. Eskimos also acquired European goods by conducting raids on foreigners' camps (Trudel, 1978; Zimmerly, 1977).

While no regular face to face contact between north coast Eskimos and Europeans took place, by the late 1600's and early 1700's the Europeans' presence, or rather their demands, were felt in some of the northern regions of Labrador. The European market for whale products was great and Eskimos in the south adopted the role of middlemen in a network moving whale products and European goods. This development probably intensified trade activity along already existing formal and informal exchange networks in the northern Labrador regions. In such a system baleen and blubber would have moved south while European goods would have filtered north.

Archaeologically, evidence to support sporadic or indirect contact is hard to pin-point, but might appear as an incidental piece of iron, a few beads, small quantities of European goods found in a largely Thule context. Assemblages of this description have been recovered from Nachvak Village (IgCx-3), Staffe Island 1 (JaDb-2), and Akulialuk 1 (JcDe-6). In all likelihood metal was a principal exchange item. This suggestion stems from analyses of assemblages from Lenz Strait, Saglek (Schledermann, 1971:84), Hopedale (Bird, 1945:158), and Eskimo Island (Jordan, 1974:83), where spikes have been cold-hammered into harpoon heads, knives, and ulus, with iron blades hafted into otherwise traditional implements. The only technological change was the replacement of slate by metal. This raw material substitution previously took place in the eastern High Arctic, when Thule groups became acquainted with meteoritic and Norse iron. Prior knowledge of the qualities of metal may have prompted Eskimos to seek contact situations. In this context the economic ramifications of the slate-iron replacement are more important to consider than are the technological implications.

Recognition of baleen and blubber as marketable items must have caused a shift in perception concerning the whale as a resource. Once hunted or scavenged for subsistence reasons, whales could now provide access to rare and prestigious trade items. Whether this development precipitated an intensification of whaling or simply a more complete use of recovered animals is unclear. Nor is it known whether groups established differential access to marketable whale products.

\section{Eighteenth Century}

European goods reached northern Labrador in increasing numbers throughout the 1700's, as seen by the 18th century European materials recovered from Killinek, Komaktorvik, Nachvak, Saglek, and Hebron. In contrast to the southern collections dating to this period, the European items do not appear in overwhelming numbers.

Northern Labrador faunal collections recovered from 18th century contexts are few in number and provide little information on Eskimo subsistence practices. Sites inhabited during earlier Neo-Eskimo periods continued to be inhabited, while a few new settlements were established and houses increased in 
size. The new settlements testify to the successful occupation of the coast, while increased house size suggests cooperative economic efforts (Taylor, 1974; Schledermann, 1976; Jordan, 1974; 1978). The basic continuity of settlement locations, faunal remains, and Moravian Mission accounts suggest that people were still involved in a broad-based economy focused largely on marine resources.

Exchange networks moving traditional trade items and European goods in the 1700's have been reported. Lieutenant Roger Curtis, who travelled as far as Okak, where he conducted interviews with Eskimos, describes the ivory trade between Okak and Nachvak (1774:378):

Observing that the seal-darts of every Indian were headed with the teeth of the sea-cow, I was led to inquire, how they came by them: and particularly, as upon these instruments they seemed to fix but little value. I was informed, that they purchased them from the Indians of Nachvak, about the latitude of 60 degrees; and that those Indians were visited by multitudes of the sea-cows, in the winter, and that they killed a vast number of them.

The activities of the middlemen operating out of southern Eskimo communities were observed by the Moravian missionaries who journeyed along the Labrador coast in the mid-1700's. The missionaries noted that rather than whaling themselves, middlemen obtained whale products from more northern settlements. They provided Europeans with the whale products in exchange for European trade goods which the middlemen then sent north (Kleivan, 1966:51).

Roger Curtis and the Moravian missionary Jens Haven individually recorded the numbers of people living in settlements as far north as Nachvak. While their late 18th century figures are not comparable, both men indicate that the greatest concentrations of people were to be found around Hebron and Okak. A number of factors could have contributed to this situation: (1) the fiord and island systems of Hebron and Okak may have provided a richer, more diversified subsistence base than would the Torngat fiord regions, therefore supporting a larger number of people; (2) a seasonal influx into Hebron and Okak, for the purpose of reaping the benefits of communal whale hunts, may account for the high population concentration, as both places were near excellent whale hunting waters (Taylor, 1974:33). (3) The figures may also represent the result of an in-migration which began before the Mission's arrival in the area. This inmigration would have been attributable to the earlier European activities in the south, triggered by the Eskimos' desire for easier access to foreign goods. Finally, (4) the possibility that the area was attractive to Eskimos because of periodic visits by European ships should not be ignored.

Face to face contacts between Eskimos living in the Kaumajet region and Moravian missionaries were common after the establishment of the Nain Mission station in 1771 and the Okak Mission station in 1776. The numbers of Eskimos residing near the stations increased steadily (Kleivan, 1966:30). Archaeological and ethnohistorical information suggest that Eskimo-European contacts were still sporadic along the Torngat coast and in the Killinek region, 
where access to European goods was gained primarily through exchange networks. Long distance travel did periodically take place, as illustrated by a 1785 Mission report on the activities of a boatload of Nachvak Eskimos who acquired rifles south of Hopedale (Taylor, 1974:9).

\section{Summary}

Cooperative hunting, communal housing, extensive trade in both local and foreign goods, as well as long distance travel must have triggered a great deal of economic and social interaction within and between Eskimo settlements along the northern Labrador coast. Indeed, the early European presence in Labrador may be seen as indirectly prompting contact activity between Eskimo communities, precipitating an intensification of communal endeavours.

\section{Late Neo-Eskimo Patterns}

\section{Subsistence Patterns}

Some time in the late 1700 's or early 1800 's subsistence and settlement pattern shifts took place along the northern Labrador coast (Fig. 2). There is no archaeological evidence to suggest that Staffe Island 1, a large Neo-Eskimo sod house settlement located south of Home Island, was inhabited in the 1800's. Within the Seven Islands Bay region the sod house settlement on the outer island Amiktok was abandoned by the time Kohlmeister and Kmoch visited the area (1814:37). The number of fall-winter settlements located along coastal and inner fiord regions increased during the 19th century, to the point where small settlements of nuclear family houses were evenly dispersed along the northern coast. Many of the settlements were located in areas previously uninhabited. Faunal and artifact assemblages from 19th century components suggest major subsistence pattern changes. Many of the new, small settlements were located near seal hunting areas and by rivers, at fishing stations. Whale and walrus remains are absent from 19th century faunal assemblages, while the percentages of seal, caribou, and fox bones are high. The faunal assemblages and the settlement locations suggest a shift away from large sea mammal hunting, with an increased reliance on seals, caribou, and fish, and in some cases indicate a considerable amount of fox trapping.

Examination of Mission records reveals that in the 1800's less and less mention of the capture or sighting of whales and walrus was made, to the point that by the mid-1800's such instances were worthy of note (Elton and Ashburner, n.d.). The absence of these large sea mammals, due to either environmental changes or over-exploitation, to some degree explains the subsistence and settlement pattern changes noted above. The paucity of whale and walrus meat and blubber would have created a crisis situation for a people who kept large dog teams, as did the Eskimos of Labrador. This lack of large marine mammals must have generated a tremendous reliance on seal hunting, and possibly an intensification of caribou hunting and fishing. Seal hunting, unlike whale and walrus hunting, was not a major cooperative endeavour; hunting was done by small dispersed 
parties who had to spend a great deal of time procuring enough game for dog and human consumption.

Most 19th century artifact assemblages from the northern coast contain cartridges, and in some cases rifle parts, indicating that firearms were standard equipment along the north coast by the late 1800 's. Caribou hunting practices must have been greatly altered by the acquisition of these weapons. Rifles enabled a few hunters to procure caribou without the aid of numbers of people. Thus, the large cooperative drives would have diminished in frequency and importance. Terrain suitable for caribou drives would not have been critical to the hunt, resulting in a shift in areas where caribou would be accessible to the hunter. As regards seals, to this day they must be retrieved with the aid of harpoons, and techniques of approaching the game have not changed substantially. Therefore the standard seal hunting technology was never abandoned.

Due to problems of preservation and sampling, there are no faunal collections reflecting a major emphasis on fishing. Knowledge of this activity comes from settlement data and ethnohistorical accounts. In all likelihood fishing lances and the use of stone weirs were familiar to pre-1800 Neo-Eskimo groups. The introduction of European fish nets allowed for a more successful exploitation of this resource. The Moravian missionaries and the Hudson's Bay Company personnel encouraged this endeavour, though for different reasons.

Worried that Christian Eskimos would be tempted to stray from their newfound life styles, the Mission sought to isolate converts from larger community pressures. They provided nets to converts and emphasized fishing in the vicinity of stations as a major subsistence activity. They encouraged the caching of as much fish as possible, in order to eliminate the number of times a family would have to leave the Mission area to go hunting (Hiller, 1971:90).

In the mid-1800's the Hudson's Bay Company, whose presence in Labrador had been limited to Ungava Bay and posts in the south and interior, turned its attention to the north coast fox and fish resources. While Post personnel did not subsidize hungry people as did the Mission, they did extend credit and they distributed equipment to Eskimos whom they considered to be good hunters (Kleivan, 1966:129). They loaned out fox traps and fish nets, expecting that the furs would be traded to the posts as would a certain amount of the fish.

The development of a trapping economy is evident in late 19th century archaeology collections. For instance, faunal assemblages from small houses at Big Head 1 (IiCw-3) and Komaktorvik 1 (IhCW-1) in Seven Islands Bay include the remains of ring seals, caribou, and fox. Cartridge cases, rifle parts, as well as some glass and earthenware sherds are the remains of goods which were probably acquired from the Hudson's Bay Company Post in neighboring Nachvak Fiord.

Kleivan (1966:133) has pointed out that the north coast trapper was faced with practical problems: he relied on his dogs to gain access to the interior, but also had to supply them with enough food for such a journey. This necessitated hunting seals. He was torn between the necessity of being near the coast seal hunting, and in the interior fox trapping. In order to reduce the weight of the 
load, the trapper carried dried food goods for his own consumption. Thus, while he had more money than the seal hunter, he spent much of it on his own food and equipment.

A number of factors contributed to a shift in subsistence patterns along the northern Labrador coast, including: (1) a drop in the numbers of large sea mammals available, resulting in a reliance on caribou, seals, and fish; (2) Moravian Mission emphasis on fishing and restricted local hunting; and (3) the Hudson's Bay Company's emphasis on fox trapping and fishing. Productive hunting zones shifted from outer island and coastal areas, where a predominantly maritime oriented subsistence pattern was practiced, to inner fiord and coastal region, where both marine and terrestrial resources were available.

\section{Settlement Patterns}

To a degree the subsistence pattern changes discussed above explain the shift to a dispersed settlement pattern and a decrease in house size. New subsistence orientations, along with new hunting technologies and strategies, deemphasized the need for cooperative hunting. Dispersed hunting parties were probably advantageous given these new technologies. However, Moravian Mission and Hudson's Bay Company policies also had much to do with this settlement dispersal and the changing economic and social patterns.

Throughout the mid-1800's the lure of the south-central Labrador region continued. In 1853 the population of Okak was reported to be 411 people (Kleivan, 1966:31). The Mission emphasis on local hunting trips, and the stockpiling of food, cut down the range of areas hunted. These policies, as well as the increased number of people resident at the stations, resulted in over-hunted pockets in the vicinity of the stations. In the mid-1800's the Mission felt the over-population and sought to alleviate the situation by building "satellite" stations (Kleivan, 1966). The Hebron Mission, established in 1830 as the northernmost station, sought to enlarge the area where Mission people could hunt, while also wanting to gain new converts amongst the north coast population. While initially met with opposition, their efforts in Saglek dispersed the Saglek community. The Mission, writing in 1849, named Saglek as a fishing place for their people, stipulating that no heathens would be allowed to live or hunt in the area (Kleivan, 1966:32). Hiller (1971) and Kleivan (1966) point to the above Mission policies, as well as the Mission emphasis on the single family dwelling, as factors which led to the breakdown of social and economic cooperation within the Eskimo community.

Eskimos were quite aware of this growing schism when Kohlmeister and Kmoch travelled along the coast. The missionaries report that during their visit to Hebron they encountered non-Christian Eskimos camped on one shore, Christian Eskimos on another. The non-converts complained about the Mission Eskimos' reluctance to share food (1814:16).

The Hudson's Bay Company's presence in northern Labrador contributed to the schism within the Eskimo community. As stated earlier, the Company extended credit and loaned equipment to Eskimos whom they considered to be good hunters. Kleivan (1966:129) has pointed out that a good hunter meant a 
good fur trapper. The seal hunter could sell the Company a few seal skins and some blubber, but the cash resulting from such a sale was not much when compared with the prices and favors commanded by fox furs. The seal hunter was thus limited in his access to some European goods, such as ammunition, particularly in periods of shortage. Thus, a category of Post-affiliated Eskimo developed.

Competition between the Company and the Mission escalated in the mid1800 's when both organizations turned their attention to north coast Eskimos. In rapid succession these two groups tried to settle Saglek and Nachvak. The Mission reached the areas first, but co-existence with the Post was undesirable so they left (Kleivan, 1966:32). Thus the Saglek Lampson Post and the Nachvak Post were established.

In 1871 the Mission again sought to establish a station in the north and built a mission in Ramah Bay, the fiord system south of Nachvak. Usually the Mission opened stations in populated areas. This was not the case with Ramah Bay, which did not have a large settlement. Indeed, archaeological work has shown that prior to Mission activitiy in the area Ramah Bay never did support a large Neo-Eskimo or Paleo-Eskimo population.

Comparison of the Nachvak and Ramah Bay Eskimo settlements highlights the contrasting contact situations occurring at one time period in neighboring fiords. Nachvak's Neo-Eskimo culture history spans from the Thule period. Examinations of the archaeological collection from the 19th century at Ivitak Cove $1(\mathrm{IgCw}-1)$, a semi-subterranean sod house settlement in Nachvak Fiord near but not at the Post, reveals traditional Eskimo implements in use along with European materials. Limited faunal collections indicate that the Ivitak Cove people exploited a variety of resources, hunting seals, caribou, and walrus when available. Fox bones at the site are attributable to the Post presence in the area, and along with European goods, including evidence of the rifle, indicate EskimoPost interaction. The archaeological evidence suggests continuation of traditional life styles with adjustments to the European presence.

As mentioned earlier, archaeological investigations in the Ramah Bay area have failed to discover evidence of a large settlement prior to the Mission presence. The Eskimos resident in Ramah Bay in the late 19th and early 20th century were attracted to the area by the missionaries, and were probably devoted converts. The archaeological collections from the sod houses at the Ramah Bay station (IfCt-3) contain few traditional Eskimo implements; indeed, the assemblages are almost exclusively utilitarian European goods. Ramah Bay Mission records mention periods of abundance and periods of widespread famine in the fiord, suggesting a precarious subsistence base.

Coleman (1921) visited both areas after the European establishments had closed. He described Ivitak Cove 1 in detail noting the presence of seal intestine windows, the use of soapstone pots, the presence of a European stove and a kettle. The Nachvak Eskimos adopted European materials to their lifeway, "The old and new methods mingling (1921:26)." At Ramah he encountered Eskimos occupying Mission buildings and living in a "tidier" or more European fashion. 
Archaeological work along the northern coast isolated late 19th century settlements around North Aulatsivik. Faunal assemblages indicate that the people residing here hunted seals and caribou, and fished. The settlements are not near European establishments and contain both European goods and traditional soapstone and bone tools. The Hudson's Bay Company Nachvak Post Journals and the early 1900 Burwell Moravian Mission records make reference to a group of Eskimos living in this area. Nachvak Post personnel travelled to North Aulatsivik and traded with the people there, but did not consider the North Aulatsivik population "Post"' Eskimos. The Mission referred to them as a group of heathens. It appears, then, that a third kind of Eskimo settlement existed along the coast, made up of Eskimos who remained unaffiliated with European groups. Indeed, distance from European settlements may have been a key factor in their settlement placement. Whether the small late 1800 sod house settlement in Bear's Gut (IeCs-1) was a similar outpost is unclear.

Trade networks between Eskimo communities were no longer in operation in the 19th century, either because there was no market for trade items such as slate and nephrite, or because items such as feathers could be exchanged directly at local trading posts. Economic activity was no longer between Eskimos, but took place directly between an Eskimo and a European. Thus, though fiords such as Saglek and Hebron, Nachvak and Ramah Bay, contained neighboring settlements, there was little economic or social interaction between the communities.

\section{Summary}

Factors which contributed to the establishment of dispersed settlements along coastal and inner fiord regions of northern Labrador included: (1) development of new subsistence orientations and strategies where hunting by small dispersed parties was advantageous; (2) Moravian Mission establishment of satellite stations along the north coast; and (3) Hudson's Bay Company expansion into northern Labrador. Due to competition between the Mission and the Company, these groups demanded loyalty from Eskimos with whom they dealt. Along the north coast three categories of individuals developed: those loyal to the Mission, those trading with the Company, and those not affiliated with either organization. Settlements reflecting these categories have been tentatively identified in the northern regions.

The overall impact of the 19th century subsistence and settlement pattern changes was the abandonment of communal hunting and sharing practices with dispersed, small hunting and trapping parties becoming the norm. Large multiple family houses disappeared in many areas, and settlements consisted of small nuclear family structures. Economic and social loyalties shifted away from the settlement or multiple family house to a particular European group. Trade networks between Eskimo communities were no longer necessary. These developments led to a breakdown of economic and social ties within and between Eskimo communities.

\section{SUMMARY}

Archaeological work has revealed evidence of a long and intense occupation of the northern Labrador coast by Neo-Eskimo groups. During the Thule period 
major fiord and island systems south to the Kaumajet region were inhabited by people practicing a broad based maritime oriented economy, with a primary focus on the procurement of large sea mammals. In all likelihood, cooperative hunting endeavours as well as exchange in locally available faunal and lithic resources prompted economic and social interaction within and between various Thule groups.

The European presence in southern Labrador during the late 1600's and early 1700's, as well as sporadic European-Eskimo contacts along the north coast, had economic repercussions in the northern regions, though not with the same intensity or speed as in the southern areas. In the north, the European presence was felt indirectly and sporadically; changes were subtle and initially involved minor technological and economic adjustments. Gradually, the European market for whale products, and the Eskimo market for trade items, triggered an intensification and broadening of activities along existing trade networks, as whale products moved south and European goods filtered north. The early Neo-Eskimo period, then, can be characterized by a great deal of social and economic activity within and between north coast communities.

During the 1800's large sea mammals were no longer available to Neo-Eskimo hunters in numbers seen earlier. This was a factor which contributed to an increased reliance on seals and terrestrial resources. This subsistence orientation change, the introduction of new hunting technologies, and the development of new hunting strategies caused the gradual elimination of cooperative hunting practices and large cohesive village settlements.

With its expansion into northern Labrador, the Moravian Mission introduced policies which emphasized residence close to Mission stations, fishing, local hunting, and caching of food as major subsistence strategies, as well as residence in single family units. In dealing with north coast Eskimos the Hudson's Bay Company also emphasized an individual's economic self-reliance, and strongly encouraged trapping and fishing. Both European groups demanded an individual's loyalty. Partially responding to these conditions, three categories of settlements developed on the north coast in the late 19th century: those following Mission teachings, those trapping and fishing for the Company, and those with limited contacts with either European group. Nineteenth century settlements shifted away from once productive whale and walrus hunting areas, principally at the sina, to coastal and inner fiord regions, where both terrestrial and marine resources could be exploited. Proximity to European settlements was also a factor in settlement locations.

The elimination of a cooperative economy and the development of alliances to particular resident European groups brought about a breakdown in economic and social ties within the north coast Eskimo community. Exchange networks were no longer necessary, interaction with neighboring communities was discouraged, and within settlements economic exchange was between an individual hunter or trapper and a European. Settlements distributed along the north coast during the late 19th century became increasingly economically and socially isolated from one another. 


\section{ACKNOWLEDGEMENTS}

The opportunity to undertake research concerned with Northern Labrador's NeoEskimo prehistory came through participation in the Torngat Archaeological Project. Research has been funded through a National Science Foundation grant to William Fitzhugh and Richard H. Jordan, a Smithsonian Scholarly Studies grant to William Fitzhugh and a Sigma Xi pre-doctoral award to the author. I would like to express my appreciation to all TAP crew members for providing me with data on Neo-Eskimo structures I was unable to investigate. Particular thanks are extended to Mary K. Whelan for her able assistance in the field and in the lab, and to William Fitzhugh for his helpful comments on earlier versions of this paper.

\section{REFERENCES}

BIRD, J. 1945. Archaeology of the Hopedale area, Labrador. Anthropological Papers of the American Museum of Natural History 39(2). $186 \mathrm{pp}$.

COLEMAN, A. P. 1921. Northeastern part of Labrador, and New Quebec. Memoir 124, No. 106 Geological Series. Ottawa: Canadian Department of Mines Publication No. 1863.

CURTIS, R. 1774. Particulars of the country of Labrador extracted from papers of Lieut. Roger Curtis, of His Majesty's Ship Oner, with a plane chart of the coast. Philosophical Transactions of the Royal Society of London 64(2): 372-387.

ELTON, C. AND ASHBURNER, P. n.d. Extracts from the Periodical Accounts of the Moravian Missions 1791 Onwards. Ms. on file N.Y. Zoological Society.

HILLER, J. 1971. Early patrons of the Labrador Eskimos: The Moravian Mission in Labrador, 1764-1805. In: Paine, R. (ed.). Patrons and Brokers in the East Arctic. Newfoundland Social and Economic Papers No. 2. Memorial University of Newfoundland. Institute of Social and Economic Research. pp. 74-97.

JORDAN, R. H. 1974. Preliminary report on archaeological investigations of the Labrador Eskimo in Hamilton Inlet in 1973. Man in the Northeast 8: 77-89.

1978. Archaeological investigations of the Hamilton Inlet Labrador Eskimo: Social and economic responses to European contact. Arctic Anthropology 15(2): 175-185.

Killinek Diary. 1925. Ms. Moravian Mission Station, Nain, Labrador.

KLEIVAN, H. 166. The Eskimos of Northeast Labrador: A history of Eskimo-White Relations 1771-1955. Oslo: Norsk Polarinstitutt Skrifter No. 139. 196pp.

KOHLMEISTER, B. and KMOCH, G. 1814. Journal of a Voyage from Okak on the Coast of Labrador to Ungava Bay, Westward of Cape Chudleigh. London: W. M. McDowall. 83 pp.

KUPP, J. and HART, S. 1976. The Dutch in the Strait of Davis and Labrador during the 17 th and 18 th centuries. Man in the Northeast 11: 3-20.

Nachvack Post (Esquimaux Bay District) Journals 1868-1905. Ms. Hudson Bay Company Archives. Winnipeg, Canada.

SCHLEDERMANN, P. 1971. The Thule tradition in Northern Labrador. Unpublished M.A. thesis, Memorial University of Newfoundland.

1976. Thule culture communal houses in Labrador. Arctic 29(1): 27-37.

TAYLOR, J. G. 1974. Labrador Eskimo settlements of the early contact period. Publications in Ethnology No. 9. Ottawa: National Museum of Man. $102 \mathrm{pp}$.

TRUDEL, F. 1978. The Inuit of Southern Labrador and the development of French sedentary fisheries (1700-1760). In: Preston, R. (ed.). Canadian Ethnology Service Paper No. 40: 99-121.

ZIMMERLY, D. W. 1977. Cain's Land revisited: Culture change in central Labrador. Newfoundland Social and Economic Studies No. 16. Memorial University of Newfoundland. Institute of Social and Economic Research. 346 pp. 